\title{
On the etiology of an outbreak of winter dysentery in dairy cows in Brazil ${ }^{1}$
}

\author{
Paulo E. Brandão $2,5^{*}$, Laura Y.B. Villarreal ${ }^{2,5}$, F. Gregori ${ }^{3,5}$, Silvio L.P. de Souza ${ }^{2}$, \\ Marco A.E. Lopes ${ }^{2}$, Cleise R. Gomes ${ }^{2}$, Angelo J. Sforsin ${ }^{4}$, Alexandre A. Sanches ${ }^{2,5}$, \\ Cesar A.R. Rosales ${ }^{2,5}$, Leonardo J. Richtzenhain ${ }^{2,5}$, Antonio J.P. Ferreira ${ }^{2}$ and \\ José A. Jerez ${ }^{2,5}$
}

\begin{abstract}
Brandão P.E., Laura Y. B. Villarreal L.Y.B., F.Gregori F., Souza S.L.P., Lopes M.A.E., Gomes C.R., Sforsin A.J., Sanches A.A., Rosales C.A.R., Richtzenhain L.J., Ferreira A.J.P. \& Jerez J.A. 2007. On the etiology of an outbreak of winter dysentery in dairy cows in Brazil. Pesquisa Veterinária Brasileira 27(10):398-402. Faculdade de Medicina Veterinária e Zootecnia, Universidade de São Paulo, Av. Prof. Dr. Orlando Marques de Paiva 87, São Paulo, SP 05508-270, Brazil. E-mail: paulo7926@yahoo.com

Winter dysentery (WD) is a seasonal infectious disease described worldwide that causes a marked decrease in milk production in dairy cows. In the Northern hemisphere, where the disease is classically recognized, bovine coronavirus $(\mathrm{BCoV})$ has been assigned as a major etiologic agent of the disease. Nonetheless, in the Southern hemisphere, an in-deep etiological survey on WD cases had not been carried out. This study aimed to survey for BCoV by nested-RT-PCR, rotavirus by polyacrylamide gel electrophoresis (PAGE) and ELISA, bacteria by classical bacteriological methods and PCR for virulence factors and parasites by sugar flotation test on fecal samples of 21 cows from a farm during an outbreak of WD in São Paulo state, Southeastern Brazil. BCoV was detected in all 21 samples, while rotavirus was detected in two symptomatic cows. Escherichia coli, Yersinia intermedia, Providencia rustigianii Proteus penneri, Klebsiella terrigena and Enterobacter aglomerans were detected in samples from both asymptomatic and healthy cows in different associations. The study of $E$. coli virulence factors revealed that the strains isolated were all apathogenic. Cysts of Eimeria sp. and eggs of Strongyloidea were detected at low numbers in four of the symptomatic cows, with one co-infestation. These results suggest $\mathrm{BCoV}$ as the main etiologic agent of the cases of WD in Brazil, a conclusion that, with the clinical and epidemiological patterns of the disease studied herein, match those already described elsewhere. These findings give basis to the development of preventive measures and contribute to the understanding of the etiology of WD.
\end{abstract}

INDEX TERMS: Bovine coronavirus, etiology, winter dysentery.

\footnotetext{
${ }^{1}$ Received on April 20, 2007.

Accepted for publication on August 16, 2007.

${ }^{2}$ Faculdade de Medicina Veterinária e Zootecnica (FMVZ), Universidade de São Paulo (USP), Avenida Prof. Dr. Orlando Marques de Paiva 87, Cidade Universitária, São Paulo, SP 05508-270, Brazil. *Corresponding author: paulo7926@yahoo.com

${ }^{3}$ Instituto Biológico de São Paulo, Rua Conselheiro Rodrigues Alves 1252, Vila Clementina, São Paulo, SP 04014-002, Brazil.

${ }^{4}$ Clínica Veterinária Angelo J. Sforsin, Rua Paulo Soares Hungria Jr 599, Jardim Itália, Itapetininga, SP 18201-770, Brazil.

${ }^{5}$ Coronavirus Research Group,FMVZ, USP, Av. Prof. Dr. Orlando Marques de Paiva 87, Cidade Universitária, São Paulo, SP 05508-270.
}

RESUMO.- [Sobre a etiologia de um surto de disenteria de inverno em vacas leiteiras no Brasil.. Em vacas leiteiras, a disenteria de inverno (DI) é uma doença infecciosa sazonal mundialmente relatada que ocasiona uma marcada queda na produção de leite; no hemisfério Norte, onde a doença é classicamente reconhecida, o coronavirus bovino ( $\mathrm{BCoV}$ ) tem um importante papel como agente etiológico. Entretanto, no hemisfério Sul, pesquisas etiológicas aprofundadas em casos de DI nunca forma realizadas. Este estudo objetivou a pesquisa de $\mathrm{BCoV}$ utilizando nested-RT-PCR, rotavírus utilizando eletroforese em gel de poliacrilamida (PAGE) e ELISA, bactérias com métodos bacteriológicos clássicos e PCR para fato- 
res de virulência e parasitas pela técnica de flutuação em açúcar em 21 amostras fecais de vacas de uma fazenda durante um surto de DI no estado de São Paulo, Sudeste do Brasil. BCoV foi encontrado em todas as 21 amostras, enquanto que rotavírus foi encontrado em duas vacas sintomáticas. Escherichia coli, Yersinia intermedia, Providencia rustigiani, Proteus penneri, Klebsiella terrigena e Enterobacter aglomerans foram encontradas tanto em amostras de vacas sintomáticas quanto assintomáticas. $\mathrm{O}$ estudo de fatores de virulência para $E$. coli revelou que as amostras isoladas eram todas apatogênicas. Cistos de Eimeria sp. e ovos de Strongyloidea foram encontrados em baixos números em quatro animais sintomáticos, com uma co-infestação. Tais resultados sugerem o BCoV como o principal agente etiológico em casos de DI no Brasil, uma conclusão que, somada aos padrões clínicos e epidemiológicos da doença aqui estudada, concordam com aqueles descritos em outras regiões. Estes achados fornecem base o desenvolvimento de medidas preventivas e também contribuem para o entendimento sobre a etiologia da DI.

TERMOS DE INDEXAÇÃO: Coronavírus bovino, disenteria de inverno, etiologia.

\section{INTRODUCTION}

Winter dysentery (WD) is an acute epizootic infectious disease with a seasonal occurence and worldwide distribution that affects adult cattle, with a higher prevalence amongst dairy cows. The disease has already been associated with bovine coronavirus (BCoV), torovirus, rotavirus, bovine viral diarrhea virus, Salmonella sp., Crysptosporidium parvum and Eimeria bovis (Campbell \& Cookingham 1978, Koopmans et al. 1991).

The disease was formally first described by Horner et al. (1975) and has already been reported in countries such as France, Sweden, Korea, Japan, Canada, USA and Brazil (Jactel et al. 1990, Alenius et al. 1991, Milane et al. 1995, Fukutomi et al. 1999, Cho et al. 2000, Brandão et al. 2002, Jeong et al. 2005).

The yearly outbreaks may last up to 10 days, the symptoms starting during the winter months, initially in a small number of cows. In a few days, up to $100 \%$ of the herd may be affected with acute and severe dysentery, which might be bloody, with the excretion of large amounts of enteric tissue, depressed body condition, dehydratation and marked decrease in milk production (Tråven et al. 2001).

Though often reported in dairy herds from the Northern hemisphere, many aspects related to WD in the Southern hemisphere, such as microbiological and clinical findings are still largely unknown (Brandão et al. 2002).

The purpose of this study was to establish the etiology of a WD outbreak in a Brazilian dairy herd based on an extensive cross-sectional microbiological and parasitological examination of both affected and non-affected animals in order to contribute to the elucidation of WD etiology in the tropics.

\section{MATERIALS AND METHODS}

\section{Case history and sampling}

During the Brazilian winter month of July 2003, in a dairy farm with 190 Black-and-white Holstein lactating cows, located in Paranapanema county, São Paulo state, southeastern Brazil, $80 \%$ of the herd started showing acute and sudden symptoms of enteric disease such as diarrhea and blood dysentery and marked decrease in milk production. The cows had been vaccinated against IBR, BVD and leptospirosis. During the outbreak, no neonatal calf diarrhea (CD) was noticed in the farm and, besides this outbreak, no diarrhea or dysentery occurred in the adult cows in any other month of the year. After three days of the onset of the symptoms, all cows recovered without treatment with no fatality.

Rectal fecal samples were collected at random from 21 cows (Table 1), representing $11 \%$ of the herd, being 18 symptomatic (age varying from 2 years and 2 months to 7 years and 2 months) and three asymptomatic cows (age varying from 5.5 to 6.5 years) during the course of the outbreak and stored under refrigeration until analysis.

\section{Coronavirus detection}

The 21 samples were prepared as $20 \%(\mathrm{v} / \mathrm{v})$ suspensions in phosphate buffer saline solution $0.01 \mathrm{M} / \mathrm{BSA} 0.1 \% \mathrm{pH} 7.2$ (PBS) and clarified by centrifugation $\left(12,000 \mathrm{xg} / 30 \mathrm{~min}\right.$ at $\left.4^{\circ} \mathrm{C}\right)$. A nested-RT-PCR assay targeted to amplify a 136-bp fragment of group II coronaviruses RNA-dependent RNA-polymerase gene $(R d R p)$ was applied as described by Brandão et al. (2005). Bovine coronavirus Kakegawa strain (Akashi et al. 1980) was used as positive and PBS as negative controls, respectively.

Total RNA from the fecal suspensions was extracted with TRIzol reagent (Invitrogen ${ }^{\mathrm{TM}}$ ) according to manufacturer's instructions and $7 \mathrm{~mL}$ of each extracted RNA re-suspended in DEPC-treated water were denatured at $95^{\circ} \mathrm{C}$ for $5 \mathrm{~min}$ and added to c-DNA mix containing $1 \mathrm{x}$ First Strand Buffer (Invitrogen ${ }^{\mathrm{TM}}$ ), $1 \mathrm{mM}$ of each dNTP, 10mM DTT, $1 \mu \mathrm{M}$ of each primer [sense primer 2Bp 5' ACTCARWTRA ATYTNAAATAYGC 3' and anti-sense primer 4Bm 5' TCACAYTTWG GATARTCCCA 3' as described by Stephensen et al. (1999)] and 200U M-MLV Reverse Transcriptase (Invitrogen ${ }^{\mathrm{TM}}$ ) to a $20 \mu \mathrm{L}$ final reaction. Reverse transcription was carried out at $42^{\circ} \mathrm{C} / 60 \mathrm{~min}$.

Next, $5 \mu \mathrm{L}$ of c-DNA were added to the PCR mix [1xPCR Buffer (Invitrogen ${ }^{\mathrm{TM}}$ ), $0.2 \mathrm{mM}$ of each $\mathrm{dNTP}, 0.5 \mu \mathrm{M}$ of each primer (2Bp and $4 \mathrm{Bm}), 1.5 \mathrm{mM} \mathrm{MgCl}, 25.25 \mu \mathrm{L}$ ultra-pure water and $1.25 \mathrm{U}$ Taq DNA polymerase (Invitrogen ${ }^{\mathrm{TM}}$ ) to a $50 \mu \mathrm{L}$ final reaction] and submitted to 6 cycles of $94^{\circ} \mathrm{C} / 1 \mathrm{~min}, 40^{\circ} \mathrm{C} / 2 \mathrm{~min}$ and $72^{\circ} \mathrm{C} / 1 \mathrm{~min}, 36$ cycles of $94^{\circ} \mathrm{C} / 1 \mathrm{~min}$, $50^{\circ} \mathrm{C} / 1.5 \mathrm{~min}$ and $72^{\circ} \mathrm{C} / 1 \mathrm{~min}$, followed by $72^{\circ} \mathrm{C} / 10 \mathrm{~min}$ for final extension.

The second round of amplification was carried out with $5 \mu \mathrm{L}$ of first PCR product added to the PCR mix [1xPCR Buffer (Invitrogen ${ }^{\mathrm{TM}}$ ), $0.2 \mathrm{mM}$ of each $\mathrm{dNTP}, 0.5 \mu \mathrm{M}$ of each internal primer (sense primer CV2U 5'TACTATGACTGGCAGAATGTTTCA 3' and anti-sense primer CV2L 5'AACATCTTTAATAAGGCGRCGTAA 3' as described by Brandão et al. ), $1.5 \mathrm{mM} \mathrm{MgCl}_{2}, 25.25 \mu \mathrm{L}$ ultra-pure water and $1.25 \mathrm{U}$ Taq DNA polymerase (Invitrogen ${ }^{\mathrm{TM}}$ )] and submitted to 26 cycles of $94^{\circ} \mathrm{C} / 1 \mathrm{~min}, 54.8^{\circ} \mathrm{C} / 1.5 \mathrm{~min}$ and $72^{\circ} \mathrm{C} / 1 \mathrm{~min}$ followed by $72^{\circ} \mathrm{C} / 10 \mathrm{~min}$ for final extension.

An ultra-pure water-containing tube was used as nested negative control every three sample tubes, also added mix and submitted to thermocycler to monitor amplicon contamination. Furthermore, in order to avoid any laboratory contamination, each step (RNA extraction, reverse transcription and PCR, nested and electrophoresis) was carried out in separate rooms with separate materials.

Ten microliters of the nested product were analyzed in $1.5 \%$ agarose gel electrophoresis stained with $0.5 \mathrm{mg} / \mathrm{mL}$ ethidium bromide and visualized under UV light.

\section{Rotavirus detection}

The fecal samples were searched for rotavirus 11-segmented RNA in PAGE (polyacrylamide gel electrophoresis) according to Herring et al. (1982). All samples were prepared as $20 \%$ suspensions $(\mathrm{v} / \mathrm{v})$ in TRIS (base) $0.1 \mathrm{M} \mathrm{pH7.3}$ and clarified by centrifugation $(12,000 \mathrm{xg} /$ $30 \mathrm{~min}$ at $4^{\circ} \mathrm{C}$ ). Total RNA was extracted with phenol/ clorophormium, 
precipitated with ethanol and resolved in 3.5\%/7.5\% discontinuous polyacrylamide gel under $20 \mathrm{~mA}$ for 2 hours and silver stained. The NCDV (Nebraska Calf Diarrhea Virus) rotavirus strain (Mebus et al. 1969, White et al. 1970) was included as positive and TRIS (base) $0.1 \mathrm{M} \mathrm{pH7.3}$ as negative controls, respectively.

As a parallel test, a double-sandwich ELISA for group A rotavirus detection (Gregori et al. 2000) was also applied to the same fecal suspensions, with the NCDV strain as positive and TRIS (base) $0.1 \mathrm{M}$ pH7.3 as negative controls, respectively.

\section{Parasitological examination}

Oocysts of Cryptosporidium sp. and Eimeria sp. and cysts of Giardia sp. and Strongyloidea eggs were searched in $20 \%$ suspensions of the 21 fecal samples in PBS (v/v) with the sucrose flotation test (specific gravity 1.205 ) with an optical microscope as described by Ogassawara \& Benassi (1980).

\section{Bacteriological analysis}

Detection and identification of bacteria started with pre-culture of fecal samples in Brain Heart Infusion (BHI) $\left(\right.$ Difco $^{\mathrm{TM}}$ ) medium at $37^{\circ} \mathrm{C}$ for $24 \mathrm{~h}$. Subsequently, for isolation of the bacterial genera and species from the enteric tract, Agar MacConkey and XLT4 media were used and incubated at $37^{\circ} \mathrm{C}$ for $24-48$ hours as described by Krieg \& Holt (1986).

The bacteria isolated were then submitted to biochemical identification, essentially, as described by Holt et al. (1994).

\section{Escherichia coli virulence factors}

All E. coli-positive fecal samples were surveyed for the presence of the virulence factors VTE, F18, K88, P987, K99, F41, LT, STA and STB by PCR according to the method described by Blanco et al. (2006).

\section{RESULTS}

The results from the microbiological and parasitological examinations in the 21 fecal samples are summarized in Table 1 .
The nested-RT-PCR for coronavirus resulted positive in all 21 samples and no cross-contamination was detected after agarose gel electrophoresis of the negative controls reactions.

No rotavirus or other segmented-RNA virus was detected with PAGE, but the ELISA for group A rotavirus resulted positive in two samples, both from symptomatic cows.

Bacteriological analysis revealed Yersinia intermedia (2 samples), Providencia rustigianii 2 samples), Proteus penneri (1 sample), Klebsiella terrigena (1 sample) and Enterobacter agglomerans (4 samples) as common findings in eight of the samples from symptomatic cows, with one $Y$. intermedia/ $E$. agglomerans and one P.penneri/ K. terrigena co-infection.

Escherichia coli was isolated from 11 samples, being 8 from symptomatic and three from asymptomatic cows, with one $E$. coli/ $Y$. intermedia co-infection in one the last. The study of $E$. coli virulence factors revealed no virulence factors in 10 out of the $11 \mathrm{E}$. coli strains detected; one sample could not be processed for virulence factors due to insufficient amount.

Eggs of Strongyloidea sp. were detected in three and oocysts of Eimeria sp. in two out of the 21 samples, being one coinfection, all in symptomatic animals and at a low number.

\section{DISCUSSION}

An outbreak of dysentery in dairy cows from a farm located in Southeastern Brazil has been described with clinical, seasonal and microbiological findings compatible to those reported in cases of winter dysentery in the Northern hemisphere.

The clinical features of the enteric disease observed in the symptomatic animals studied herein, which included blood diarrhea with severe loss of enteric tissue and the marked decrease in milk production, are similar to signs considered

Table 1. Virological, bacteriological and parasitological examinations on 21 fecal samples from cows during an outbreak of winter dysentery in Southeastern Brazil

\begin{tabular}{|c|c|c|c|c|c|c|}
\hline Sample & Dys $^{\mathrm{a}}$ & $\begin{array}{l}\text { BCoV } \\
\text { (PCR) }\end{array}$ & $\begin{array}{c}\text { RoV } \\
\text { (PAGE/ELISA) }\end{array}$ & $\begin{array}{c}\text { Bacteriological } \\
\text { examination }\end{array}$ & $\begin{array}{l}\text { coli virulence } \\
\text { factors }\end{array}$ & $\begin{array}{c}\text { Parasitological } \\
\text { examination }\end{array}$ \\
\hline 96 & $P$ & $P$ & $\mathrm{~N} / \mathrm{P}$ & Yersinia intermedia & NT & $\mathrm{N}$ \\
\hline 299 & $\mathrm{~N}$ & $P$ & $\mathrm{~N} / \mathrm{N}$ & Escherichia. coli & NT & $\mathrm{N}$ \\
\hline 387 & $\mathrm{~N}$ & $P$ & $\mathrm{~N} / \mathrm{N}$ & Y. intermedia/ E. coli & $\mathrm{N}$ & $\mathrm{N}$ \\
\hline 587 & $P$ & $P$ & $\mathrm{~N} / \mathrm{N}$ & Providencia rustigianii & NT & $\mathrm{N}$ \\
\hline 841 & $P$ & $P$ & $\mathrm{~N} / \mathrm{N}$ & Proteus penneri/Klebsiella terrigena & NT & Eimeria $\mathrm{sp} /$ Strongyloidea \\
\hline 850 & $\mathrm{P}$ & $P$ & $\mathrm{~N} / \mathrm{N}$ & E. coli & $\mathrm{N}$ & $\mathrm{N}$ \\
\hline 868 & $\mathrm{P}$ & $P$ & $\mathrm{~N} / \mathrm{N}$ & E. coli & $\mathrm{N}$ & Strongyloidea \\
\hline 887 & $P$ & $P$ & $\mathrm{~N} / \mathrm{N}$ & E. coli & $\mathrm{N}$ & $\mathrm{N}$ \\
\hline 923 & $P$ & $P$ & $\mathrm{~N} / \mathrm{N}$ & E. coli & $\mathrm{N}$ & $\mathrm{N}$ \\
\hline 933 & $\mathrm{P}$ & $P$ & $\mathrm{~N} / \mathrm{N}$ & Enterobacter aglomerans & NT & $\mathrm{N}$ \\
\hline 934 & $P$ & $P$ & $\mathrm{~N} / \mathrm{N}$ & $\mathrm{N}$ & NT & $\mathrm{N}$ \\
\hline 938 & $\mathrm{P}$ & $P$ & $\mathrm{~N} / \mathrm{N}$ & E. coli & $\mathrm{N}$ & Strongyloidea \\
\hline 972 & $P$ & $P$ & $\mathrm{~N} / \mathrm{N}$ & Y. intermedia/ E. aglomerans & NT & $\mathrm{N}$ \\
\hline 978 & $P$ & $\mathrm{P}$ & $\mathrm{N} / \mathrm{P}$ & $\mathrm{N}$ & NT & $\mathrm{N}$ \\
\hline 1005 & $\mathrm{~N}$ & $P$ & $\mathrm{~N} / \mathrm{N}$ & E. coli & $\mathrm{N}$ & $\mathrm{N}$ \\
\hline 1174 & $P$ & $P$ & $\mathrm{~N} / \mathrm{N}$ & E. aglomerans & NT & $\mathrm{N}$ \\
\hline 1275 & $\mathrm{P}$ & $P$ & $\mathrm{~N} / \mathrm{N}$ & P. rustigiani & NT & Eimeria $\mathrm{sp}$ \\
\hline 9146 & $P$ & $P$ & $\mathrm{~N} / \mathrm{N}$ & E. coli & $\mathrm{N}$ & $\mathrm{N}$ \\
\hline 9215 & $P$ & $P$ & $\mathrm{~N} / \mathrm{N}$ & E. aglomerans NT & $\mathrm{N}$ & \\
\hline 9219 & $P$ & $P$ & $\mathrm{~N} / \mathrm{N}$ & E. coli & $\mathrm{N}$ & $\mathrm{N}$ \\
\hline 9224 & $P$ & $P$ & $\mathrm{~N} / \mathrm{N}$ & E. coli & $\mathrm{N}$ & $\mathrm{N}$ \\
\hline
\end{tabular}

a Dys= dysentery, $\mathrm{P}=$ positive, $\mathrm{N}=$ negative, $\mathrm{NT}=$ not tested, $\mathrm{BCoV}=$ bovine coronavirus, RoV= rotavirus. 
for the clinical diagnosis of WD, mainly the acute onset of bloody diarrhea in adult cows (Takahashi et al. 1980, Dea et al. 1995) and the short lasting period of three days (Campbell \& Cookingham 1978). These findings allow one to speculate that cows affected by WD in the Southern hemisphere will experience a similar clinical course observed in the Northern hemisphere in countries with a more well-defined winter.

Bovine coronavirus was detected in all 21 samples under study, including three from asymptomatic cows. The finding of $\mathrm{BCoV}$ in the three asymptomatic cows may be due to the fact that they were in the incubation period, which may be from 48 hours under experimental infection (Tråven et al. 2001) to up to a week under natural conditions (Campbell \& Cookingham 1978). Accordingly, due to the high sensitivity of PCR (Forghani \& Erdman 1994), these samples may have been positive prior to the clinical manifestations of $\mathrm{BCoV}$ infection.

All samples were negative to rotavirus by PAGE, but two out of the 18 symptomatic animals were positive to group $A$ rotaviruses by ELISA. Group A rotavirus has been tentatively proposed as playing a major role on the etiology WD (Sato et al. 1997), but reports on adult bovine symptomatically infected by rotaviruses are scarce. Groups B and C rotaviruses have also been detected in fecal specimens of cows with WD, but at low frequencies (Parwani et al. 1996, Chang et al. 1997, Mawatari et al. 2004).

Not surprisingly, all bacteria isolated from the fecal samples belong to the Enterobacteriaceae. Klebsiella terrigena is an opportunistic pathogen of animals found in unpolluted surface water and soils (Bagley 1985); Enterobacter aglomerans is found on different species of plants, most interestingly in grains (Zucker et al. 2000). Hence, for these two bacteria, the transmission may have occurred via contaminated water or food, but the low frequency of isolation of these suggests their role, if any, as secondary pathogens in the outbreak under study.

Providencia rustigiani and P. penneri are also opportunistic pathogens that may cause primary or secondary infections and which are more frequently associated infections of the urinary tract (Hickman-Brenner et al. 1983, Pignato et al 1999). Their role as etiologic agents of enteritis, although suggested, has not been definitively established (Muller 1986). Thus, in the cases studied herein, this finding might be regarded as fortuitous and a contamination of the feces with urine during sample collection as a source of $P$. rustigianni and $P$. penneri isolation can not be ruled out.

Yersinia intermedia is a pathogen contaminating water and food that infects humans and wild and domestic animals as well, frequently leading to gastrointestinal disorders (Punsalang et al. 1987, Sulakvelidze 2000). On the other hand, based on the low frequency of $Y$. intermedia isolation (2 isolates out of 18 symptomatic cows) and the simultaneous isolation of other bacteria (one E. coli and one E. aglomerans strain in each case), a determinant role of $Y$. intermedia in the pathogenesis in the clinical cases presented can not be assigned.

Regarding the $E$. coli strains detected in 11 out of the 21 samples, as no virulence factor could be evidenced after PCR analysis on 10 of these, such strains are suggestive of being non-pathogenic $E$. coli of the normal enteric microbiota of cattle and the failure to detect this bacteria in the remaining 8 cows can be attributed to the loss of the normal microbiota as a consequence of acute enteritis.

The exact species of Eimeria found in two samples could not be determined due to the low accuracy of differentiation of its oocystis under optical microcopy. In cattle, the most common species are E. bovis and E. zuernii, responsible for severe hemorrhagic diarrhea with substantial economic loss for the cattle industry, but these, contrary to what was found in the studied case, occur in calves 3 to 6 months old (Daugschies \& Najdrowski 2005).

Strongyloidea, although causing enteric processes and disease in cattle, (Guimaraes et al. 2000), have never been reported as causing acute dysentery in cows and, most importantly, have been found at very low numbers in a restricted number of samples in the animals here studied and might thus be disregarded in an etiological view.

The cause of the seasonal pattern observed in WD might be the immunosuppression that cows may suffer during months of low temperature. For instance, as described by Crouch \& Acres (1984), normal cows shed BCoV in their feces, but the excretion occurs mostly as immunecomplexes, probably of the IgA-BCoV class, what avoids virus attachment and thus pathogenesis.

Nonetheless, in an immunossupressed cow, secretory IgA would occur in lower titers and a chronic infected cow would have free $\mathrm{BCoV}$ in the gut capable to produce infection and cause enteritis

Brazilian strains of BCoV detected in calves have been described in which an 18 nucleotide-long deletion was found in the hypervariable region of the envelope glycoprotein gene, indicating that two $\mathrm{BCoV}$ lineages occur in the country (Brandão et al. 2006).

Whether Brazilian strains of WD BCoV fall in only one or two of the described lineages of Brazilian BCoVs and whether these have differences in virulence when compared to $\mathrm{CD} B \mathrm{CoV}$ remain to be answered.

Although some studies on the comparison among WD and $\mathrm{CD}$ strains of $\mathrm{BCoV}$ evidenced no major serological or genetic differences (Dea et al. 1995), others have suggested a strongest enzymatic activity of the hemagglutinin-estarese (HE) envelope proteins of some WD BCoV strains as the biological marker responsible for a high virulence in cows (Gelinas et al. 2001).

The present article is the first description of an in-deep microbiological/ parasitological survey of cases of WD in the Southern hemisphere associated with a clearly-defined clinical entity and might help to design preventive measures such as vaccination schedules to increase the herd immunity, early detection of BCoV-carrier animals and selection of specific treatments such as anti-viral therapies to chronically infected cows.

As a conclusion, an outbreak of winter dysentery in Brazilian dairy cows was studied in which bovine coronavirus can be assigned as the primary etiologic agent, with clinical and epidemiological features compatible to those described in countries were WD is classically described. 


\section{REFERENCES}

Akashi H., Inaba Y., Miura Y., Tokuhisha S., Sato K. \& Satoda K. 1980. Properties of a coronavirus isolated from a cow with epizootic diarrhea. Vet. Microbiol. 5:265-276.

Alenius S., Niskanen R., Juntti N. \& Larsson B. 1991. Bovine coronavirus as the causative agent of winter dysentery: serological evidence. Acta Vet. Scand. 32:163-170.

Bagley S.T. 1985. Habitat association of Klebsiella species. Infect. Control 6:5258.

Blanco M., Lazo L., Blanco J.E., Dahbi G., Mora A., Lopez C., Gonzalez E.A. \& Blanco J. 2006. Serotypes, virulence genes, and PFGE patterns of enteropathogenic Escherichia coli isolated from Cuban pigs with diarrhea. Int. Microbiol. 9:53-60.

Brandão P.E., Birgel Jr E.H., Gregori F., Rosales C.A.R., Ruiz V.L.A. \& Jerez J.A. 2002. Bovine coronavirus detection in adult cows in Brazil. Arqs Inst. Biológico, São Paulo, 69:103-104.

Brandão P.E., Gregori F., Villarreal L.Y.B., Rosales C.A.R., Soares R.M. \& Jerez J.A. 2005. A nested polymerase chain reaction to bovine coronavirus diagnosis. Virus Rev. Res. 10:45-49.

Brandão P.E., Gregori F., Richtzenhain L.J., Rosales C.A.R., Villarreal L.Y.B. \& Jerez J.A. 2006. Molecular analysis of Brazilian strains of bovine coronavirus $(\mathrm{BCoV})$ reveals a deletion within the hypervariable region of the $S 1$ subunit of the spike glycoprotein also found in human coronavirus OC43. Arch. Virol. 151:1735-1748.

Campbell S.G. \& Cookingham C.A. 1978. The enigma of winter dysentery. Cornell Vet. 68:423-441.

Chang K.O., Parwani A.V., Smith D. \& Saif L.J. 1997. Detection of group B rotaviruses in fecal samples from diarrheic calves and adult cows and characterization of their VP7 genes. J. Clin. Microbiol. 35:2107-2110.

Cho K.O., Halbur P.G., Bruna J.D., Sorden S.D., Yoon K.J., Janke B.H., Chang K.O. \& Saif L.J. 2000. Detection and isolation of coronavirus from feces of three herds of feedlot cattle during outbreaks of winter dysentery-like disease. J. Am. Vet. Med. Assoc. 217:1191-1194.

Crouch C.F. \& Acres S.D. 1984. Prevalence of rotavirus and coronavirus antigens in the feces of normal cows. Can. J. Comp. Med. 48:340-342.

Daugschies A. \& Najdrowski M. 2005. Eimeriosis in cattle: current understanding. J. Vet. Med. B Infect. Dis. Vet. Public Health, 52:417-427.

Dea S., Michaud L. \& Milane G. 1995. Comparison of bovine coronavirus isolates associated with neonatal calf diarrhoea and winter dysentery in adult dairy cattle in Quebec. J. Gen. Virol. 76:1263-1270.

Forghani B. \& Erdman D. 1994. Amplification and detection of viral nucleic acids, p.97-120. In: Schmidt J.N. \& Emmons R.W. (ed.), Diagnostic Procedures for Viral, Rickettsial and Chlamydial Infections. American Public Health Association, Washington, DC.

Fukutomi T., Tsunemitsu H. \& Akashi H. 1999. Detection of bovine coronavirus from adult cows with epizootic diarrhea and their antigenic and biological diversities. Arch. Virol. 144:997-1006.

Gelinas A.M., Boutin M., Sasseville A.M. \& Dea S. 2001. Bovine coronaviruses associated with enteric and respiratory diseases in Canadian dairy cattle display different reactivities to anti-HE monoclonal antibodies and distinct amino acid changes in their HE, S and ns4.9 protein. Virus Res. 76:43-57.

Gregori F., Brandão P.E., Rosales C.A.R., Cortez A., Heinemann M.B., Richtzenhain L.J. \& Jerez J.A. 2000. Desenvolvimento de um método de ELISA para a detecção de rotavírus a partir de material fecal. Arqs Inst. Biológico, São Paulo, 67:191-194.

Guimarães M.P., Ribeiro M.F., Facuri-Filho E.J. \& Lima W.S. 2000. Strategic control of gastrointestinal nematodes in dairy calves in Florestal, Minas Gerais, Brazil. Vet. Res. Commun. 24:31-38.

Herring A.J., Inglis N.F., Ojeh C.K., Snodgrass D.R. \& Menzies J.D. 1982. Rapid diagnosis of rotavirus infection by direct detection of viral nucleic acid in silver-stained poliacrylamide gels. J. Clin. Microbiol. 16:473-477.

Hickman-Brenner F.W., Farmer J.J., Steigerwalt A.G. \& Brenner D.J. 1983. Providencia rustigianii: a new species in the family Enterobacteriaceae formerly known as Providencia alcalifaciens biogroup 3. J. Clin. Microbiol. 17:10571060.

Holt J.G., Krieg N.R., Sneath P.H.A., Staley J.T. \& Williams S.T. 1994. Bergey's Manual of Determinative Bacteriology. 9th ed. Williams and Wilkins, Baltimore.

Horner G.W., Hunter R. \& Kirkbride C.A. 1975. A coronavirus-like agent present in faeces of cows with diarrhoea. N. Z. Vet. J. 23:98.

Jactel B., Espinasse J., Viso M. \& Valiergue H. 1990. An epidemiological study of winter dysentery in fifteen herds in France. Vet. Res. Commun. 14:367379.

Jeong J.H., Kim G.Y., Yoon S.S., Park S.J., Kim Y.J., Sung C.M., Jang O.J., Shin S.S., Koh H.B., Lee B.J., Lee C.Y., Kang M.I., Kim H.J., Park N.Y. \& Cho K.O. 2005. Detection and isolation of winter dysentery bovine coronavirus circulated in Korea during 2002-2004. J. Vet. Med. Sci. 67:187-189.

Koopmans M., Van Wuijckhuise-Sjouke L., Schukken Y.H., Cremers H. \& Horzinek M.C. 1991. Association of diarrhea in cattle with torovirus infections on farms. Am. J. Vet. Res. 52:1769-1773.

Krieg N.R. \& Holt J.G. 1986. Bergey's Manual of Sistematic Bacteriology. Williams and Wilkins, Baltimore.

Mawatari T., Taneichi A., Kawagoe T., Hosokawa M., Togashi K. \& Tsunemitsu H. 2004. Detection of a bovine group $\mathrm{C}$ rotavirus from adult cows with diarrhea and reduced milk production. J. Vet. Med. Sci. 66:887-890.

Mebus C.A., Underdahl N.R., Rhodes M.B. \& Twiehaus M.J. 1969. Further studies on neonatal calf diarrhea virus. Proc. Annu. Meet. U.S. Anim. Health Assoc. 73:97-99.

Millane G., Michaud L. \& Dea S. 1995. Biological and molecular differentiation between coronaviruses associated with neonatal calf diarrhea and winter dysentery in adult cattle. Adv. Exp. Med. Biol. 380:29-33.

Muller H.E. 1986. Occurrence and pathogenic role of Morganella-Proteus-Providencia group bacteria in human feces. J. Clin. Microbiol. 23:404-405.

Ogassawara S. \& Benassi S. 1980. Infecção experimental de gatos com coração de bovino parasitado por Sarcocystis sp. Arqs Inst. Biológico, São Paulo, 47: 27-32.

Parwani A.V., Lucchelli A. \& Saif L.J. 1996. Identification of group B rotaviruses with short genome electropherotypes from adult cows with diarrhea. J. Clin. Microbiol. 34:1303-1305.

Pignato S., Giammanco G.M., Grimont F., Grimont P.A. \& Giammanco G. 1999. Molecular characterization of the genera Proteus, Morganella, and Providencia by ribotyping. J. Clin. Microbiol. 37:2840-2847.

Punsalang A. Jr, Edinger R. \& Nolte F.S. 1987. Identification and characterization of Yersinia intermedia isolated from human feces. J. Clin. Microbiol. 25:859-862.

Sato M., Nakagomi T., Tajima K., Ezura K., Akashi H. \& Nakagomi O. 1997. Isolation of serotype G8, P6[1] bovine rotavirus from adult cattle with diarrhea. J. Clin. Microbiol. 35:1266-1268.

Stephensen C.B., Casebolt D.B. \& Gangopadhyay N.N. 1999. Phylogenetic analysis of a highly conserved region of the polymerase gene from 11 coronaviruses and development of a consensus polymerase chain reaction assay. Virus Res. 60:181-189.

Sulakvelidze A. 2000. Yersiniae other than Y. enterocolitica, Y. pseudotuberculosis, and Y. pestis: the ignored species. Microbes Infect. 2:497-513.

Takahashi E., Inaba Y., Sato K., Ito Y., Kurogi H., Akashi H., Satoda K. \& Omori T. 1980. Epizootic diarrhoea of adult cattle associated with a coronaviruslike agent. Vet. Microbiol., 5:151-154.

Tråven M., Naslund K., Linde N., Linde B., Silvan A., Fossum C., Hedlund K.O. \& Larsson B. 2001. Experimental reproduction of winter dysentery in lactating cows using BCV-comparison with BCV infection in milk-fed calves. Vet. Microbiol. 81:127-151.

White R.G., Mebus C.A. \& Twiehaus M.J. 1970. Incidence of herds infected with a neonatal Calf Diarrhea Virus (NCDV). Vet. Med. Small Anim. Clin. 65:487-490.

Zucker B.A., Trojan S. \& Muller W. 2000. Airborne gram-negative bacterial flora in animal houses. J. Vet. Med. B Infect. Dis. Vet. Public Health 47:37-46. 